\title{
Governance for adaptive capacity and resilience in the U.S. water sector
}

\author{
$\underline{\text { Karen J. Baehler }}^{1}$ and $\underline{\text { Jennifer C. Biddle }}^{2}$
}

\begin{abstract}
Water utility managers play potentially important roles in current and future transitions toward more adaptive and sustainable approaches to water management. We report the results of qualitative interviews and focus groups designed to explore the perspectives of 22 water utility managers in the United States regarding pressures, challenges, and opportunities facing their organizations and communities. Overall, the study participants characterized their jobs as requiring a delicate balance between innovation and reliability, with no room for error in delivering abundant, clean water, but opportunities for creative problem-solving and forward planning. They demonstrated capacity for embracing changes that benefit the longer term future while imposing shortterm costs on their own organizations. Coding of transcripts generated 17 major themes (11 problem categories and six solution categories), which overlap meaningfully with results of previous research on resilience, adaptability, and transformability of socialecological systems. Overlapping themes include social learning and development of social capital through various forms of collaboration, communication, and citizen and stakeholder engagement, as well as capacity for innovation and sufficient authority to make decisions based on system needs without undue political interference or burdensome adherence to rigid rule structures.
\end{abstract}

Key Words: adaptation; adaptive capacity; public water system; resilience; social-ecological system; transformation; water governance regime; water utility

\section{INTRODUCTION}

Significant changes are needed in many social-ecologicaltechnological regimes to prevent collapses triggered by fast or slow variables, including climate change-related shocks, population growth, harmful extraction practices, poor land use choices, and related stressors (Pahl-Wostl et al. 2010, Olsson et al. 2014). Nonetheless, most of the actual changes underway represent little more than demonstration projects and incremental progress (Brown 2008).

The mismatch between realities and aspirations may be explained by the stickiness of management processes and institutions (Garmestani and Benson 2013), many of which become institutionalized for good reasons (Marlow et al. 2013) but then persist long past their usefulness (Raven et al. 2010), and ultimately harden into rigidity traps (Holling and Gunderson 2002, Marschke and Berkes 2006, Young 2010). Researchers are keen to identify factors that can overcome such traps and increase the probability that a vulnerable social-ecological system (SES) will undergo appropriate types of change - either by adapting within a regime or transforming to a new regime as needed for the sake of human and ecosystem survival and flourishing (Walker et al. 2004, Folke et al. 2010, Olsson et al. 2014).

Although panaceas are illusory (Ostrom 2007), research suggests that some governance structures and practices support SES adaptability and transformability better than others (Yohe and Tol 2002, Dietz et al. 2003, Brooks et al. 2005, Gallopin 2006, Engle 2011, Pahl-Wostl 2017). They do so by helping key actors navigate transitions adeptly, which includes preparing for, recognizing, and using windows of opportunity for change (Olsson et al. 2006, Young 2010). Navigational abilities apply at the micro level of socio-technological organization where actors can facilitate experimentation within strategic niches and shadow networks (Raven et al. 2010, Bos and Brown 2012). They also apply at the meso level where actors are needed to disseminate experimental findings beyond the niche, modify everyday practices based on lessons learned, coordinate across scales, and manage larger tensions within and between constantly shifting regimes (de Graaf and van der Brugge 2010, Jørgensen 2012).

Human agency clearly matters throughout transition processes (de Graaf and van der Brugge 2010, Berkes and Ross 2013, Olsson et al. 2014). As international consensus grows in favor of more adaptive and integrative water governance regimes, we might expect actors within those regimes to feel increased pressure to become entrepreneurs, leaders, and change agents who embrace deep change. But, do they?

We approach those questions from the perspective of actors who manage water and wastewater utilities - organizational control points that profoundly influence how people use water in their daily lives (Wiek and Larson 2012). Previous scholarship has shed some light on this group of actors, especially through surveys and interviews conducted by transition management researchers in Australia and the Netherlands (Brown 2008, de Graaf and van der Brugge 2010, Marlow et al. 2010, Bos and Brown 2012, Ries et al. 2016). The findings from those studies provide valuable information about water professionals' views on various researcher-defined topics, including the relationship between sustainability planning and asset management (Marlow et al. 2010), and alignment with the sustainable urban water management paradigm (Brown 2008).

Missing from the growing body of scholarship is a summary of water professionals' unprompted priorities, particularly the views of water utility managers regarding pressures, challenges, and opportunities facing their organizations and communities. The resulting gap in knowledge merits attention because of the potentially significant role of these individuals in shaping the water paradigm of the future. Positioned at the intersection of technology, policy implementation, and public service delivery,

${ }^{1}$ American University, ${ }^{2}$ University of North Carolina Wilmington 
Table 1. Composition of study sample

\begin{tabular}{|c|c|c|c|c|c|c|}
\hline \multicolumn{2}{|c|}{ Location } & \multicolumn{4}{|c|}{ Population served } & \multirow[t]{2}{*}{ Totals } \\
\hline Study region & U.S. EPA Region ${ }^{\dagger}$ & $\begin{array}{c}\text { Less than } \\
100,000\end{array}$ & $\begin{array}{c}100,000- \\
500,000 \\
\end{array}$ & $\begin{array}{l}500,001- \\
1 \text { million } \\
\end{array}$ & $\begin{array}{c}\text { More than } \\
1 \text { million } \\
\end{array}$ & \\
\hline New England & 1 & $\sqrt{ }$ & & & $\sqrt{ }(2)$ & 3 \\
\hline Mid-Atlantic & 2 and 3 & $\sqrt{ }$ & $\sqrt{ }$ & $\sqrt{ }(2)$ & $\sqrt{ }$ & 5 \\
\hline Southeast & 4 & & $\sqrt{ }(2)$ & $\sqrt{ }$ & & 3 \\
\hline Great Lakes & 5 & & $\sqrt{ }$ & & $\sqrt{ }$ & 2 \\
\hline South Central & 6 & & $\sqrt{ }$ & & & 1 \\
\hline Midwest & 7 & $\sqrt{ }$ & & & & 1 \\
\hline Southwest & 9 & & & & $\sqrt{ }(3)$ & 3 \\
\hline Pacific Northwest & 10 & $\sqrt{ }(3)$ & & & $\sqrt{ }$ & 4 \\
\hline Totals & & 6 & 5 & 3 & 8 & 22 \\
\hline
\end{tabular}

${ }^{\dagger}$ For a map of the U.S. Environmental Protection Agency's regions, see https://www.epa.gov/aboutepa/visiting-regional-office

water utility managers can function as leaders, followers, facilitators, or obstructors of transitions, with serious implications for SES outcomes (Brown 2005, Loorbach 2010, Marlow et al. 2013).

If water managers are to be involved productively at all stages of the water governance transition process-from structuring problems to envisioning new pathways, mobilizing supporters, making and executing plans, monitoring progress, evaluating results, and capturing learning (Loorbach 2010, Pahl-Wostl et al. 2010) - then their approaches to such tasks must be well understood. We contribute to deeper understanding of transitional potential by compiling water managers' wide-ranging perspectives on water sector problems and solutions, and examining them in the context of related research findings.

\section{METHODS}

Our logic of inquiry proceeds both "from the inside," by exploring the perspectives of personnel in frontline organizations, and "from the outside," by engaging with the research community's central findings on SES governance transitions (Evered and Louis 1981:385).

\section{Recruitment and participants}

Recruitment of the sample was purposive. All 22 participants were senior managers or directors of water utility organizations and were employed by different organizations in different cities. Private or investor-owned utilities were excluded due to differences in key governance factors and because most of the drinking water in the United States flows through public systems. Small, rural systems also were excluded due to significant differences in the types of challenges facing those systems.

A pool of 63 potential interviewees was identified through an internet search for water utilities in coastal cities of the United States (to reduce one source of sample variation) that posted managers' contact information online. Initial contact occurred via email invitations that described our research process and included the interview guide. Follow-up phone calls were made to those who did not reply to the emails and to schedule phone interviews with those who indicated a willingness to participate. Focus group invitees were selected from a list of all registrants (not limited to coastal areas) for the American Water Works
Association's (AWWA) annual convention whose contact information was available online (total of 161 invitees).

Distribution of the final sample by size and location of utility is shown in Table 1. Both interviewees and focus group attendees are included.

\section{Data collection and analysis}

The interview guide used in both interviews and focus groups (Appendix 1) was designed to elicit the subjects' own priorities and concerns, independent of researchers' priorities. To prevent the conversations from being colored by subjects' reactions to particular words that may have acquired political connotations in some settings (such as resilience and sustainability), the interview guide used a small number of nontechnical, plainlanguage concepts (Ospina et al. 2018):

- organizational goals and priorities;

- internal challenges/stresses faced by the organization, including governance;

- external challenges/stresses faced by the organization, including weather, etc.;

- actions to address the challenges; and

- lessons learned.

Interviews and focus groups began with an open-ended request: "Tell me about your agency and its priorities," and went on to ask about the concepts just listed. If a participant did not mention the term "resilience," the protocol prompted for it near the end of each conversation. The canvas was open for participants to steer the discussion in directions that reflected their interests and concerns.

We conducted 40-minute (average) phone interviews with 14 individuals. Two focus groups (total eight participants) of approximately 75 minutes duration each were conducted inperson at the AWWA conference location by two moderators. All discussions were audio recorded with participants' permission. A notetaker attended the focus groups and recorded the order of speakers and notable behaviors. Interviewers and a research assistant transcribed all 12 hours of recordings using NVivo. Participants verified the accuracy of transcribed interviews and provided comments on preliminary results. 
Fig. 1. Level 2 axial codes derived from interview and focus group transcripts.

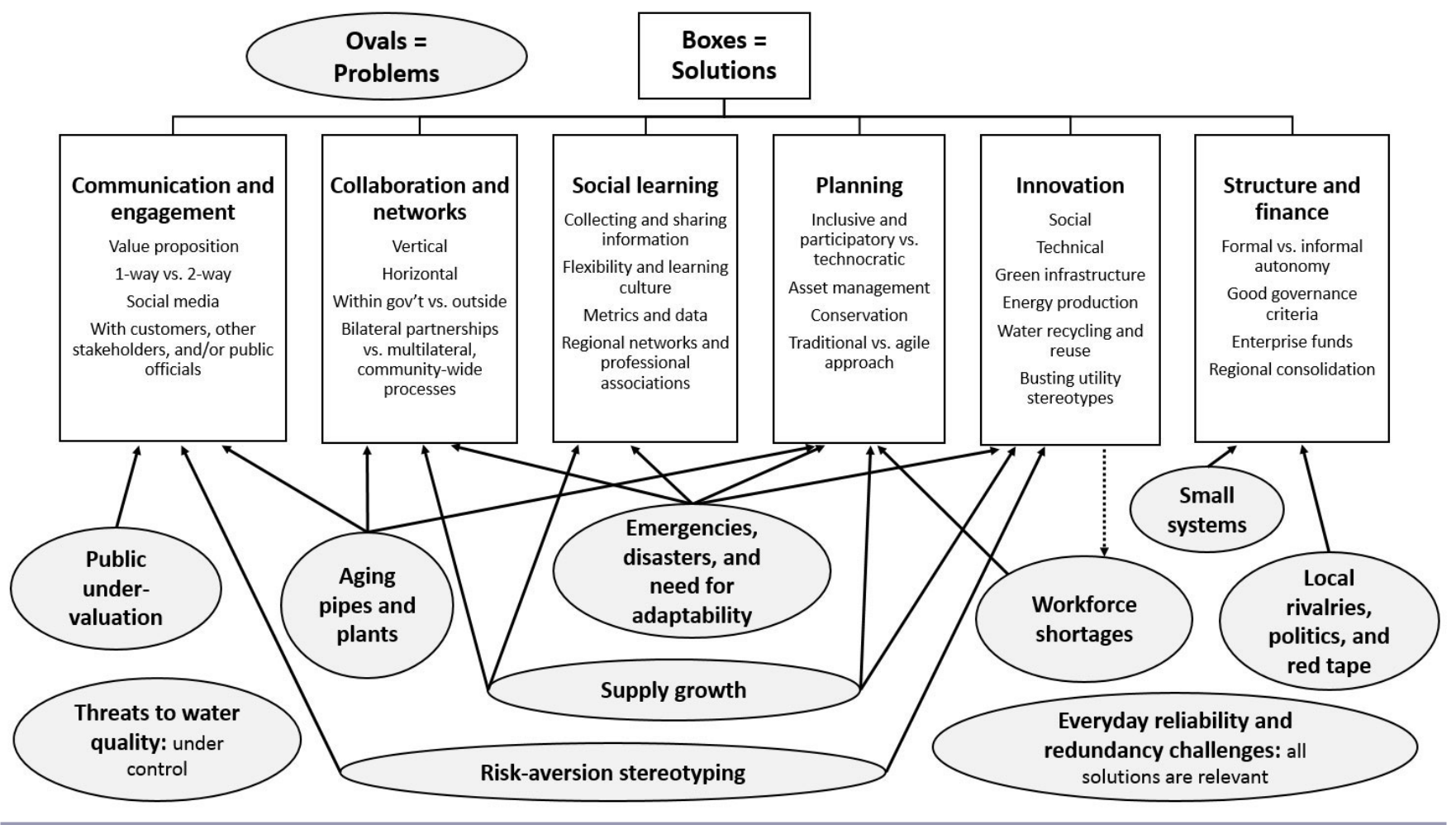

The analysis proceeded in four stages. In the first, which corresponds with Yin's (2016) "disassembling" phase of qualitative research, each author undertook an independent coding exercise covering all 16 transcripts - 14 interviews and two focus groups. This involved identifying each distinct idea being expressed by a participant, marking the phrases or sentences associated with that idea, and then labeling each idea with a natural-language tag such as "aging infrastructure concern" or "complaint about regulations." This exercise, known as level one open coding (Corbin and Strauss 2015), generated 80 separate tags, or codes, nearly all of which were applied to more than one transcript. Each transcript contained at least one dozen level one codes. In the second stage, which corresponds with Yin's (2016) "reassembling" phase, the level one codes were consolidated into successively smaller numbers of broader constructs, eventually settling on 16 level two (or axial) codes meant to capture the central ideas contained in the transcript data (Fig. 1). For example, level one open codes such as "low attendance at public meetings" and "outreach through bill inserts" would be consolidated into "communication and engagement." Lengthy discussion between the authors led to mutual agreement on the axial codes.

The third phase of analysis consisted of a holistic rereading of each raw, uncoded transcript to note the overall thrust of the managers' narratives and draw more general impressions. This method roughly corresponds with an abductive approach to qualitative research (Ong 2012). In the fourth phase, which was undertaken in response to reviewers' comments, the authors copied and pasted all coded pieces of transcript data into a spreadsheet organized by axial code themes as a recheck of coding logic. In addition, numerical counts of participants who raised each topic were noted in order to gauge the relative level of representativeness of the various consolidated (axial) codes or themes.

Consolidating codes required interpretation of the data. In order to strengthen the validity of the final code structure, the two researchers actively challenged each other's interpretations during the iterative coding and recoding process, and study participants were invited to comment on preliminary findings. Coding was done using NVivo software.

Although saturation (i.e., the point at which no new level one concepts are raised by participants) was reached after eight to 10 interviews, we continued to conduct interviews because we had willing subjects. The focus groups raised two new level one concepts not covered in the interviews - aging workforce and supply-chain challenges during disasters.

\section{RESULTS}

While the interviews and focus groups generated a wide range of specific examples and considerable variability in emphasis, similar broad themes were raised over and over again, as depicted by the 10 problem categories (ovals) and six solution categories (boxes) of Fig. 1. Some comments from study participants also provided information about which solutions are meant to address which problems, as shown by the arrows in Fig. 1. This section reports results from the data analysis. 
Note: Arrows point from problems identified by participants to the solutions suggested for those problems. The dotted arrow pointing from innovation to workforce shortages represents the fact that adoption of more sophisticated technological innovations increases pressure to hire more technical workers in the water sector, which contributes to the problem of worker shortages.

\section{Water sector challenges}

When asked open-ended questions about their organizations' goals, participants nearly always used the words reliability or dependability (10 interviewees and both focus groups), or referred to related concepts of service performance (four interviewees). Threats to that goal of reliability ranked high on participants' lists of challenges. Sea level rise and other effects of climate change (storms, flooding, drought) were identified as major, long-standing priorities in two of three interviews on the Pacific coast and four of nine on the Atlantic coast, and as a moderate priority for one additional east coast interviewee. Neither of the Great Lakes interviewees expressed concerns about climate change, and most focus group members did not use the term.

Apart from climate change, nearly all participants either raised the topic of emergencies and disasters or reinforced the theme through supportive comments or body language in the focus groups. (The exceptions were the two Great Lakes interviewees.) Supply chain disruption during earthquakes or storms was a major topic in the first focus group. Earthquakes and tsunamis were specified as concerns on the west coast, saltwater intrusion into aquifers in the Southeast, and winter storms in New England. Loss of power from large weather events was a common concern across the country, except for three interviewees who had high confidence in their backup generators (assuming access to diesel fuel).

The challenge of building public support for system maintenance and upgrades was clearly on managers' minds. With a few exceptions, the prevailing view was that customers "don't want to pay, and don't understand, the real cost of water" (interviewee, Southeast), largely because "[i]t's out of sight, out of mind...they take it for granted" (interviewee, Great Lakes). The topic also arose in both focus groups, with the word "complacency" used in one to describe typical public attitudes.

Public undervaluation of water was closely tied to another highpriority concern for 10 interviewees and all members of both focus groups: the increasingly urgent need to replace pipes and plants, many of which were built and installed 50 to 100 or more years ago. The challenge of aging infrastructure came up early in both focus groups and many interviews. Participants often expressed frustration with local elected officials who avoid politically unpopular moves to fund necessary replacements. And on a related point, six interviewees and multiple participants in both focus groups expressed frustration with local politics generally (e.g., "rivalries," "grudges"), and especially the pressure to compete for funding and attention from elected officials.

A related problem of perception arose in both focus groups and five interviews: that is the stereotype of utilities as excessively risk averse. All participants who mentioned the issue noted that utilities cannot engage in experimentation as freely as other organizations because of potential consequences for public health, the environment, and fire suppression. They wanted the public to see risk aversion in water utilities as a virtue rather than a bureaucratic infirmity.

Five interviewees and several members of the second focus group noted multiple special challenges facing smaller water systemsincluding lack of redundancy, difficulties raising capital, and small-town rivalries that stifle cooperation. Small systems struggle particularly hard to meet regulatory requirements, according to one interviewee.

Animated discussions arose in both focus groups over the obstacles to hiring younger workers with technical skills, and the implications for future workforce shortages. By contrast, only four interviewees raised similar concerns.

The question of where to find additional water sources to accommodate future economic and population growth was a major discussion topic in the first focus group (less so in the second) and for six interviewees spread between both sea coasts. Six other interviewees expressed confidence about water quantity either because they sat on ample groundwater, had spare capacity due to population decline in the past, or were located on the Great Lakes. The topic of water quality did not make most participants' lists of headline worries. Although everyone ranked delivery of clean water as a top priority, they also noted that strict regulations combined with well-established testing and treatment methods made it relatively routine. Only one interviewee mentioned emerging challenges from microparticles and pharmaceuticals. Two focus group members fretted about groundwater contamination in their regions.

\section{Addressing the challenges}

When asked about how their organizations and cities are responding to system stressors, participants most frequently touched on the six solution categories (boxes) in Fig. 1. Attention was fairly evenly divided among the six categories, with 11 interviewees emphasizing each of the first four themes (communication and engagement, collaboration and networking, social learning, and planning), 10 highlighting innovation, and eight emphasizing structure and finance. All six categories featured prominently in both focus groups.

\section{Communication and engagement}

Nearly all study participants noted the importance of outreach to customers, rate payers, and citizens, but they emphasized different purposes of communication:

- sharing information about utility performance and problems (transparency);

- obtaining support for planned changes (water rate increases especially, but also septic-to-sewer conversions, and water reuse in the future);

- encouraging water user behaviors (such as conservation);

- building a political base-_Customers can be our allies to hold off elected officials" (focus group participant, Southwest); and more generally,

- addressing public undervaluation of water services and public perception of utilities as rigid and anti-innovation (one of the water sector themes). 
Participants also emphasized the need to keep key government administrators and elected officials informed via a range of formal and informal meetings, discussions, and educational sessions. On average, participants tended to view communication, engagement, and collaboration as instrumental activities necessary for achieving their organization's goals rather than as open processes for exploring alternative futures.

Many approached communication as a bit of a chore, while others embraced it and spoke with pride about the long hours that they devoted to it. Among the latter, three interviewees in particular forcefully argued that both the public and elected officials can be awakened to the value of water and the need to invest in it, but only if utilities make a continuous commitment to educating people about the water business and sharing information about system issues, including financing challenges. Those managers emphasized the importance of demonstrating transparency to build trust, and then making the case for capital investments: "I've learned that people are open to hearing what the value proposition is. And that is our job, to make that claim... [that water system investments are] the best money they will ever spend and something that will matter to them more than anything" (interviewee, Mid-Atlantic).

Points of emphasis varied. One interviewee said that his organization's communication strategy prioritizes public officials over the general public (Pacific Northwest). Another interviewee warned that it is hard to get things done "with the public sitting in our offices" (interviewee, Pacific Northwest). In general, however, interviews and focus groups generated strong consensus on the need for wide-ranging outreach with rate payers, customers, stakeholders, and public officials. These participants expressed a belief that such processes can lead to sustained cooperation to offset political tensions about rate increases and increase appreciation for public drinking water services.

The most commonly noted communication methods tended to be one-directional (annual reports and bill inserts), but two-way methods such as Twitter and Facebook were mentioned. Some participants noted obstacles to fuller engagement: "The trick is the two-way communication. We send a lot. Sending is easy. Receiving is hard." (focus group participant, Pacific Northwest).

Two interviewees, both from small utilities, said that public outreach is not a priority for their organizations. According to one of these, "our customers know where to find us" if they need to communicate (Mid-Atlantic).

\section{Collaboration and networking}

Participants described a wide range of types of collaboration, from sharing of information and resources to joint goal setting and decision-making across different sectors, among water providers, or between departments within government. Crosssector collaboration commonly occurred with roads and transportation departments - "so that we tear the street up one time and share in the restoration costs" (interviewee, Midwest) and with electric utilities. Examples of the latter include providing reclaimed water for cooling nuclear and coal power plants, scheduling high-power-using activities at water plants to avoid periods of peak electricity demand, and generating electricity from waste. Participants described additional bilateral partnerships with landfills, hospitals, airports, neighborhood associations, Indian tribes, and the U.S. Coast Guard for a range of mutual benefits. Managers who cited concerns about the effects of climate change were most likely to discuss the value of broader, cross-sector, and multilateral networks focused on system-level resilience planning. Participants placed a high value on mutual assistance as a form of horizontal collaboration within the water sector, as exemplified by the Water/Wastewater Response Network (WARN). The importance of WARN was stressed by multiple study participants, some of whom had benefited directly from its work coordinating the sharing of emergency aid and assistance (personnel, equipment, materials, and services) between nearby utilities.

Without using the term social capital directly, participants implied the concept in both focus groups and at least three interviews when describing benefits gained through local and regional collaborations of various types. One interviewee (Pacific Northwest) said that the importance of local collaboration in securing new water sources was the single most important lesson he had learned as a water manager. In his words, "Everybody looks at the resource a little differently, but everybody wants it for some reason. So you have to work collaboratively.... Bring all of the stakeholders in and get everybody's needs met as best you can. It's going to take a lot longer to do that in a way, but you'll actually get to a solution instead of ending up in court." Where water rights are involved, power-sharing appears to be a fact of life rather than an aspiration.

Alongside the benefits of collaboration, all but one participant also noted significant points of tension within networks due to competing organizational agendas. In vertical, cross-scale networks that bridge federal, state, and local levels of government, participants noted the particular challenges of working with multiple agencies' different priorities and cultures.

\section{Social learning}

Communication, citizen engagement, collaboration, and networks together create potential for social learning in which community members collect and share information that helps improve an SES's capacity for adaptation and resilience. Only two interviewees were silent about learning. Eleven interviewees and members of both focus groups articulated ideas related to an organizational learning culture and described a diverse array of manifestations. These included adaptive management-type approaches to water system management, pilots and demonstrations, internal competitions, and portfolios of projects for developing new water sources (so that there is always a replacement when one initiative fails). Participants mentioned sharing technology and governance lessons via regional conferences and exchanges of smart practices between small systems under the aegis of a regional water authority. Seven interviewees referred to data dashboards or other performancemetric systems as important inputs to learning. Two small systems relied on contracts with outside firms to keep them up to date on technical developments. The importance of learning channels within professional associations, such as the AWWA and the Water Resources Foundation, received frequent mentions in both focus groups and interviews.

When asked to define resilience, several interviewees and focus group members included capacity for learning as a strategy for dealing with unforeseen system stresses. 


\section{Planning}

Participants often noted the important role of planning in the same breath as flexibility, resilience, and learning, especially in the focus groups. Among the 11 interviewees and members of both focus groups who spoke with pride about their own utility's planning efforts, some emphasized an inclusive, participatory approach to planning (particularly where the issue of future water supplies was a major concern), while others described a more technocratic approach focused on infrastructure replacement. In the latter case, the process known as asset management came up repeatedly. Conservation was viewed as a central component of planning in seven interviews and the first focus group. Some commenters touted the savings that successful conservation efforts create when new plants do not have to be built, while others noted complications when revenue losses from conservation have to be covered by rate increases.

Three of the 11 interviewees who talked about planning took what might be called an agile approach to planning: one large utility described their conservation planning initiatives as a carefully crafted trial-and-error process. One small utility described how they built rolling infrastructure replacement into day-to-day operations. A third interviewee described an iterative and participatory approach to community-wide resilience planning.

\section{Innovation}

As noted earlier, utility managers take pride in actively avoiding risks to public health, while also embracing a continuous learning approach that invites innovative problem solving. One interviewee from a municipal enterprise in the Mid-Atlantic put it this way: "[Innovation] just needs to know that it has a home and a place, even in a water utility, where we will evaluate, be careful, but if it's a good idea and we believe it will work - because we have done the right preparatory work, which is nearly always research, classic research, bench-testing, pilot testing - we will implement it. And then people start coming forward with lots more [fresh ideas]."

Participants proudly described social innovations related to increasing conservation, organizing volunteers, promoting ecotourism to save wild areas around water sources, and leveraging local organizations' existing agendas and activities to boost community resilience. One interviewee also mentioned movements to encourage stormwater management practices at the household level. Technical innovations included green infrastructure, water reclamation projects, digesters, and alternative power generation, as well as natural engineering solutions to protect source water, such as living shorelines, wetlands treatment of wastewater, and integrated land management practices. Such projects defy the usual stereotype of utilities as resistant to change and innovation. And study participants expressed the belief that if the public knew more about these innovations, such stereotypes (one of the water sector themes) would fade. They also noted that state and federal regulations often create unnecessary obstacles to innovations such as water recycling.

\section{Structure and finance}

Study participants hailed from a diverse, multidimensional collection of organizational structures: independent authorities with elected boards, independent authorities with appointed boards, municipal departments that require city council approval of all medium-to-large expenditures, proprietary municipal departments in charge of their own revenues and expenditures, municipal departments organized around public works functions, municipal departments that combine environmental management with water services, agencies with control of their own revenues except when the city needs subsidies, regional authorities that coordinate smaller systems, wholesale sellers, retail sellers, and others.

From this heterogeneity, only three interviewees in our study said nothing about governance structure or power relationships. Among most who discussed the subject, eight interviewees and members of both focus groups expressed significant concerns about bureaucratic and political interference in utility decisions. To address those concerns, they emphasized the value of institutional autonomy, independence from politics and rigid rules, and structures that allow water managers to focus on one set of services instead of the multiple, often competing functions associated with a typical municipal department.

On the other hand, two interviewees and several focus group members employed in city departments expressed satisfaction with less formal autonomy because informal norms gave them latitude for reasonably independent decision-making. Members of the second focus group noted how formal autonomy can be misleading, as when nominally independent authorities are required to make large payments in lieu of taxes to city coffers. One interviewee and several focus group members staunchly maintained that no governance structure is necessarily better than another because performance depends on leadership, talent, and organizational culture more than structure.

The second focus group ultimately arrived at a robust consensus on two criteria for assessing good governance in the water sector: (1) ability to do full-cost pricing in order to achieve financial sustainability, and (2) ability to do long-term, system-wide planning (see Planning). Any structure that enables those functions should be judged positively, according to the group. Interviewees who addressed financing as a general topic also tended to support those ideals, and several also mentioned the principle that debt, rather than direct fees on current users, should be used to pay for capital improvements that will benefit future generations or newcomers to the area: "growth should pay for growth" (interviewee, Mid-Atlantic).

Enterprise fund arrangements in which the utility keeps its own revenue were touted by seven interviewees and members of both focus groups as supporting the two criteria: "If we have a savings, it immediately manifests itself into more capital construction out in the field. [Dollars from a recent rate increase] went right back out into the street to replace more water mains" (interviewee, Great Lakes).

Consolidating smaller systems under a regional authority, either through outright purchases or looser federation arrangements, was mentioned by five interviewees and members of the second focus group, all favorably. Benefits cited include increased reliability, redundancy, and resilience for small systems and the spreading of system-wide maintenance and upgrade costs across a larger customer base.

\section{DISCUSSION}

This study responds to calls for more research about the role of human agency in facilitating adaptation and transformation of 
SES toward greater sustainability (Olsson et al. 2014). The results provide insights into the priorities of one set of actors in adaptive governance transitions. Fig. 1's themes and subthemes may be viewed as study participants' guideposts for good governance in public water utilities in the United States.

Overall, the impression left by the participants' comments may be summarized in terms of two potentially competing commitments: cautiously creative change and rock-solid continuity of services. Similar to previous research (Farrelly and Brown 2011), most of these water utility managers saw their jobs as requiring a delicate balance between innovation and reliability, with zero room for error in delivering abundant, clean water to homes, businesses, and firefighting. Much of the technical innovation was found on the wastewater side of the organizations, with social and business innovations on the drinking water side typically focused on conservation, disaster planning, and identification of new water sources. These water managers find themselves navigating hybrid organizational vessels through multiple external challenges posed by nature and politics. Many feel underappreciated for their efforts and generally misunderstood, except within the horizontal professional networks that they tend to view as high-functioning and mutually supportive learning environments.

Viewed through the lens of the research literature, the mix of themes represented by Fig. 1 looks like a practical operationalization of the scholarly distinction between adaptation, which refers to modifying current SES settings to withstand shocks and stresses, and transformation, which refers to recreating systems anew in the face of current or future existential threats (Walker et al. 2004, Folke et al. 2010, Olsson et al. 2014). The following integrative comments address both sides of that conceptual distinction.

\section{Transformability}

Those who hope to see broad readiness for radical transformation among water sector actors may be disappointed by the results of this study. On one hand, these water managers expressed an openness to change. Only two or possibly three (all representing smaller systems) could be characterized overall as satisfied with the status quo and unperturbed about the future. All of the others expressed aspirations for progress and change. They saw room for improvement, and many spoke of the need for continuous learning and adaptation. They also demonstrated some capacity for embracing changes that benefit the longer term future while imposing short-term costs on their own organizations, conservation being the prime example of this because of its negative impact on most utilities' short-term revenue streams.

On the other hand, sustainable, integrated, whole-cycle paradigms of water management consist of many promising practices, such as rainwater capture and usage (including rooftop collection and rain gardens), effluent recycling, reuse of gray water, strict separation of waste streams, water and nutrient budgets at multiple scales, increases in pervious surfaces, stormwater detention and infiltration, groundwater storage, and extreme decentralization to self-contained water systems off the grid (Heaney et al. 2000, Li et al. 2018). But only a few of these ideas came up in our conversations, and none were treated as major themes. Participants by and large seemed to be answering our questions based on a time horizon measured in months or, in some cases, a year or two, rather than decades.
One participant spoke of transformational regime change when he noted that low-lying coastal cities must decide whether and when to abandon their infrastructure and move inland as part of an "organized retreat" in reaction to sea level rise. But he was the exception. The only interviewee who called for "a paradigm shift" was referring to changing the mindset among maintenance crews - a much narrower understanding of paradigm change than one finds in the resilience and transition literatures.

Deliberate transformations "often involve the questioning of values, the challenging of assumptions, and the capacity to closely examine fixed beliefs, identities, and stereotypes" (O'Brien 2012:670) - in other words, triple-loop learning (Pahl-Wostl 2009). Yet, the careful, function-preserving resilience that water managers necessarily embrace may hamper the disruptive, transformative regime changes that scholars are calling for. While utility managers are innovating socially and technologically within constraints at the local scale and preparing and rehearsing diligently for major system disturbances, they are also investing in the adaptability of the current water regime and thus reinforcing and reproducing it. Hardening large-scale infrastructure, upgrading centralized systems, and seeking further consolidation of smaller systems under regional umbrellas - all of these activities create sunk costs (both financially and psychologically) that make the idea of an organized retreat, radical decentralization of water services, or other paradigm shifts ever more distant and unrealistic.

On the social side of the SES equation, none of our study's participants talked about real power-sharing of the type that would require commitments from utility leaders or public officials to do more than listen. Granting some decision-making authority to a consumers' board, for example, would entail the kind of fundamental questioning of the status quo that characterizes triple-loop learning, but participants did not mention such initiatives. Some participants recognized the popular stereotype of utilities as rigid, change-averse, and lacking in creativity, and they provided a nuanced, well-reasoned explanation for why a healthy measure of those traits is necessary for drinking water systems and how those traits can co-exist with significant innovation at lower scales. Their majority (though not universal) embrace of organizational autonomy for water utilities, combined with a desire to build public support for upgrading existing systems and public understanding of water's value proposition, adds up to a sort of soft technocratic perspective on water provision as a public service business.

\section{Adaptability}

The concept of adaptation more fully captures the priority concerns of this group of study participants than does transformation. The water managers' dual orientation toward both reliability and continual learning echoes the idea that adaptive institutions should have just enough flexibility (not too much or too little) (Olsson et al. 2006, Young 2010), as well as the general recommendation of Pahl-Wostl et al. (2007:9): "For social learning to increase both the adaptive capacity and the effectiveness of water management requires a fine balance between the stabilizing and the change-supporting elements of a governance regime."

Table 2 aligns the axial-code themes from Fig. 1 with factors identified in the broad SES literature on governance for adaptive capacity and resilience, including second-tier variables from 
Table 2. Themes common to both study participants' comments and the research literature

\begin{tabular}{ll}
\hline$\overline{\text { Axial codes }} \begin{array}{l}\text { Related academic literature } \\
\end{array}$ & $\begin{array}{l}\text { Second-tier variables in } \\
\text { Ostrom }(2007,2009)^{\dagger}\end{array}$ \\
\hline
\end{tabular}

Communication and engagement

Meaningful discourse and deliberation among stakeholders, including public engagement, I3: Information sharing is vital for effective planning and decision-making (Lebel et al. 2006, 2013), selforganization and bottom-up action (Ostrom 1990, Pahl-Wostl 2017), and adaptive governance specifically (Djalante et al. 2011). It builds accountability and legitimacy (Engle and Lemos 2010).

I3: Deliberation processes

I4: Conflicts among users

Deliberation should be active and engaged, and broadly representative of diverse interests I6: Lobbying activities (Biggs et al. 2012, Lebel et al. 2013), with channels for dissent and high levels of communication overall (Olsson et al. 2006).

"Risk dialogue" needs to be supported by open access to information (Pahl-Wostl et al 2010) and participatory forms of management (Olsson et al. 2004, Folke 2006), including participatory scenario development (Pahl-Wostl 2009).

But balance is needed between bottom-up and top-down processes; both are importan (Pahl-Wostl 2009).

Not all actors appreciate an open and inclusive approach to participation; there will be obstacles (Bos and Brown 2012).

Collaboration and networks

Social networks build social capital, which enhances adaptive capacity and resilience (Adger et al. 2005, Folke 2006, Pahl-Wostl et al. 2007, Tol and Yohe 2007).

Collaborative, networked governance fosters trust and enables learning and reframing of issues (Pahl-Wostl 2009, Newig et al. 2010, Huntjens et al. 2012).

Shadow networks enable transition pathways when dominant networks are resistant to change (Olsson et al. 2006). Informal, self-organized networks play key roles in adaptive governance (Djalante et al. 2011), and links between formal and informal organizations and networks are vital (Pahl-Wostl 2017).

Information diffuses through modularized networks (Allenby and Fink 2005), aided by dynamic bridging organizations that facilitate exchange of ideas and mobilization of collective effort across scales and across groups and interests, including experts, users, and power holders (Pahl-Wostl et al. 2007, Engle and Lemos 2010), and between science, policy, and community (Koop and van Leeuwen 2015).

Therefore, flexibility and openness are vital traits of networks for adaptation (Gunderson et al. 2006).

Genuine collaboration also depends on real sharing of power (Adger et al. 2005, PahlWostl et al. 2010, Olsson et al 2014). Polycentric systems disperse authority across multiple organizations or network nodes, while also supplying effective coordination (McGinnis and Ostrom 2011)

Professional networks build knowledge and expertise but may reinforce technocratic elitism. Open networks of citizens/users plus external stakeholders are needed (Farrelly and Brown 2011).

Social learning

Learning from past experience with shocks and stressors builds adaptive capacity and resilience (Adger 2003, Berkes and Ross 2013). Crises open windows of opportunity for learning and change (Folke et al. 2010), including both double- and triple-loop learning (Pahl-Wostl et al. 2007, Pahl-Wostl 2009, Parthasarathy and Natesan 2015).

"Management as learning" depends on experimentation (Huntjens et al. 2012:67). Lessons from diverse local experiments in strategically protected niches help drive transitions (Seixas and Berkes 2003, Walker et al. 2006, Schot and Geels 2008, Farrelly and Brown 2011, Huntjens et al. 2012, Jørgensen 2012).

Additional learning platforms that can facilitate cross-scale learning beyond niches (Folke et al. 2010) and build up alternative regimes (Loorbach 2010) are needed. Networks may fill that role (Olsson et al. 2006, Walker et al. 2006, Loorbach 2010) while also serving as repositories for institutional memory (Djalante et al. 2011).

Social learning aids transition by challenging conventional beliefs (Bos and Brown 2012). Diversity of ideas and practices is vital (Folke et al. 2010).

(Rapid) feedback, monitoring, early warning systems, adaptive management, and perpetuating local memory are features of adaptive learning (Adger et al. 2005, Berkes and Seixas 2005, Folke 2006, Young 2010, Carpenter et al. 2011). Learning requires access to knowledge and opportunities to use information, which are key components of adaptive capacity (Engle and Lemos 2010).

Failure should be reconceived as a learning opportunity (Farrelly and Brown 2011).
GS3: Network structure

U6: Shared norms, social capital, trust

I7: Self-organizing activities

I8: Networking activities

7: Knowledge of the social-ecological system and its attributes, including how users' actions affect the resource system
Water managers emphasized instrumental messaging to build understanding, appreciation, and support for water services among citizens, consumers, and elected officials, including public education about the value proposition. Scholars emphasize fuller engagement via a more participatory model, and water managers also value greater engagement to some degree. Their aspirations toward two-way communication tend to outpace their actual practices, however, partly because water consumers are not necessarily clamoring to engage (unless rate hikes are on the agenda).
Water managers described bilateral partnerships and cooperation more often than the multiparty and multilevel collaborations favored by scholars. How do those bilateral relationships compare to a single, community-wide collaboration in terms of building adaptive capacity? Utilities needing to secure additional water sources, and those focused on climate change-related threats appear to find broad stakeholder networks especially important for success. Only a few water managers mentioned social capital or related concepts. The theme of full-blown powersharing was not raised by participants.
Water managers were keenly aware of social learning and described an embedded culture of organizational learning as vital to system resilience. Their examples of learning were very diverse, without a clear pattern, but none fit the scholars' ideal of triple-loop learning (fundamental rethinking of assumptions). Many water managers were more naturally inclined to learn horizontally from peers in other utilities via professional networks and mutual aid collaborations. Vertical learning, by contrast, was fraught with politics and could threaten a utility's autonomy. 
Planning

Effective planning and decision-making require meaningful stakeholder and public engagement (Lebel et al. 2006, 2013)

Adaptive and integrated water regimes take an evolutionary approach to management and planning processes (Pahl-Wostl et al. 2010).

That approach includes maintaining a portfolio of projects, ready for a window of opportunity to open (Olsson et al. 2006, Young 2010), and "a repertoire of potential solutions to unforeseen problems and unpredictable variations" (Engle 2011:648).

Climate change adaptation work, such as drought preparedness, seems to work best when decentralized but with centralized capacity to support comprehensive planning (Engle 2013).

Innovation

When adaptive systems reorganize following a crisis, they need new ideas, technologies, mutations, and recombinations of traits to fill social and ecological niches (Holling and Gunderson 2002).

Therefore, arenas/spaces/sites for generating novelty and innovation are vital ingredients in transition and transformation (Folke et al. 2005, de Graaf and van der Brugge 2010, Loorbach 2010). Strategic niche management requires protection of niches for experimenting with a diversity of substitute practices plus coordination across niches so that insights can be collected and shared: innovation and collaboration work together in shadow networks and strategic niches (Olsson et al. 2006, Farrelly and Brown 2011).

Transition processes also are producing broad networks for innovation composed of actors from business, government, science, and civil society (Loorbach 2010).

Note danger of backlash if experiments are perceived as too risky - risk is a serious disincentive to innovation (Farrelly and Brown 2011).

Innovation should be inclusively coproduced (Olsson et al. 2014).

Structure and financing

Power to change and enforce rules is necessary for self-organization and adaptive governance (Ostrom 1990, Lebel et al. 2006, 2013). Autonomous organizations are better able to adopt substitute practices when current practices underperform or when shocks create opportunities for disruption. For example, autonomous public corporations with own charter and board are more likely to "get prices and governance right" (Araral 2008:527).

Flexible, multilevel structures allow for small-scale revolts and recoveries in place of total collapses (Holling and Gunderson 2002, Folke et al. 2005, Olsson et al. 2006).

"Transformational change at smaller scales enables resilience at larger scales," and institutional structures can facilitate or obstruct those processes (Folke et al. 2010:1)

Many existing water management regimes do not fit their ecosystems (Young 2011, Lebel et al. 2013). Fit is improved by combining institutional forms, such as hybrids of networks, hierarchies, and markets (Pahl-Wostl et al. 2017).

New, more adaptive institutional arrangements may combine dynamic decentralization with central support and coordination (Engle and Lemos 2010, Engle 2013). Top-down and bottom-up processes need to be balanced (Huntjens et al. 2012).

In general, governance structures have significant impacts on participatory processes (Mostert et al. 2007), and well-designed, open institutions reduce the nonmonetary transaction costs of collaboration (Folke et al. 2005).

Distribution of power + coordination $($ vertical and horizontal $)=$ polycentricity and improved adaptability (Pahl-Wostl 2009, Pahl-Wostl and Knieper 2014).
RS7: Predictability of system dynamics (indirectly related as a precursor to planning)

U5: Leadership and entrepreneurship, especially the latter

U9: Technology used (may be a target or product of innovation)

GS 5: Autonomy over rule creation at collectivechoice level
The realities of infrastructure renewal require water managers to practice traditional, scripted planning, which may not align with scholarly calls for agile approaches to planning that acknowledge the unpredictability inherent in complex adaptive systems. U.S. water utilities that have placed climate change on their agendas demonstrate greater openness to more agile and participatory approaches to planning.
Many utilities embrace innovation to the extent that they can without risking actual or perceived public harm. Utilities are willing to suffer short-run revenue losses in the cause of socially beneficial innovations related to conservation, for example. Enthusiasm among water managers for water recycling is notable, as is their apparent lack of attention to highly disruptive innovations (none were mentioned). Scholars emphasize the importance of sheltered spaces for innovation.

Categories of second-tier variables used: RS = Resource System; GS = Governance System; I = Interactions (between factors); U = Users (of the natural resource in question).

Elinor Ostrom's $(2007,2009)$ diagnostic framework. (Citations in column 2 represent a selective fraction of the vast literature published to date.) The last column compares insights from our study's participants with scholarly themes. Table 2 illustrates how our participants' answers reinforce the importance of governance practices highlighted in previous research on adaptive capacity and resilience. These include social learning and development of social capital through various forms of collaboration, communication, and citizen and stakeholder engagement, as well as capacity for innovation and sufficient autonomy and authority to make decisions based on system needs without undue political interference or excessive bureaucracy.
The frequent repetition of themes across interviews and focus groups suggests some professional isomorphism in the water management field, likely aided by the professional associations that were so often mentioned. The correspondence that we found between professional and scholarly themes is more difficult to explain and merits further study. It may have resulted from cross fertilization of ideas between managers and researchers, although we saw no evidence that these particular managers were engaging with the scholarly literature. Perhaps it confirms that the research community is asking questions that touch issues of deep concern to those with direct responsibility for the resource. It also may indicate progress toward a roughly overlapping consensus on the 
best paths forward. Although many scholars support a more sweeping vision of sustainability transformation than these study participants described, the themes in Table 2 offer a shared conceptual vocabulary that may be useful in efforts to bridge those differences.

Placing the study participants' priorities and concerns in the context of the scholarly literature also identifies two stray themes that figure prominently in the scholarly literature but not in this study's data. The first is leadership, identified by researchers as a significant contributor to effective transitions and transformations; yet only one of our participants (an interviewee) mentioned it, and only very briefly. Perhaps personal modesty prevented the participants from talking about leadership directly as a theme. It could be inferred from many of their descriptions of local initiatives that they themselves were leading the work. The second is equity and social justice, another notable factor in the academic literature that did not come up in our interviews or focus groups. It is difficult to speculate responsibly about the reasons for that conspicuous absence.

Table 3 examines these additional themes using the same template as Table 2. Both of the missing themes deserve further attention in future research with water utility managers.

\section{Study limitations}

Although a qualitative study of this size typically focuses on depth of insights more than breadth of coverage, we were pleased by the heterogeneity of organizations captured in our sample and the diversity of views expressed by participants. Still, the constraints on generalizing from a qualitative, exploratory study of this kind must be acknowledged.

In addition, we note that this group of participants may have a higher average level of interest in resilience and adaptation than a randomly selected group of nonparticipants, given their willingness to participate in the study and the effort required to coordinate a phone call (interviewees) or attend a special session at the AWWA conference (focus group members).

The focus group results may have been influenced by group dynamics (as with all focus groups) or by topics being emphasized at the AWWA conference where the focus groups were convened. If so, then the interview results may capture the frank priorities of participants more reliably than the focus groups, but that supposition cannot be tested within our data.

Finally, the study's stated focus on water management may have unintentionally prompted participants to think more narrowly about public health and environmental objectives without due consideration of the larger social and political implications of their organizations' frameworks and practices. Perhaps a more explicit focus on social and political dimensions in both our questions and our interpretations of findings may have generated different conclusions.

\section{CONCLUSION}

Transitions toward adaptive governance for SES sustainability must begin where the relevant actors are positioned. For that reason, acquiring deeper understanding of water managers' current postures and priorities may be helpful in planning for effective transitions. Examining the views of 22 U.S. water utility managers in the light of scholarship on SES adaptation, resilience, transition, and transformation highlights the following questions for further research.

- Utility managers expressed deep commitment to system reliability and functional continuity, on one hand, and organizational learning and innovation on the other hand. How can this dual orientation be harnessed to facilitate necessary transitions?

- One answer to that question may be found in shadow networks and strategic niche management. If protected sites for experimentation can be found outside utilities, and if utilities do not feel pressured to take on too much fundamental risk themselves, then new ideas and approaches may be discovered elsewhere and ultimately adopted. This strategy raises additional questions: Which organizations can serve as strategic sites for experimentation outside utilities? How might such experimentation be funded?

- Mindsets and management practices that produce rocksolid dependability at the level of water and wastewater services are viewed by some as obstacles to change, but perhaps they can be viewed instead as enabling creative thinking and experimentation in broader niches and at larger scales. Does emphasis on consistent utility performance and careful prevention of public-health or environmental crises at the local level create a secure space in which public officials at the regional or national level can explore new ideas and develop new paradigms of water stewardship?

- At the scale of the utilities themselves, study participants expressed high levels of trust in horizontal networks of fellow professionals. How can those networks be used more effectively to nurture discussions about deeper forms of change, and to prepare for transitions in the water services model, where appropriate?

- What role might small water systems play in SES transition and transformation? Can their qualities of modularity and diversity be developed as resiliency assets?

- What models of leadership are most likely to facilitate shifts in focus within water managers' horizontal, professional networks? How do managers think about the role of leadership?

- To what extent do utility officials consider inequities to be part of their professional agendas, and part of their organizations' sustainability pathways?

As scholarly understanding of governance's role in SES adaptation and transformation deepens and expands, the views of frontline experts and managers can provide valuable insights and directions for future research. 
Ecology and Society 23(4): 24

https://www.ecologyandsociety.org/vol23/iss4/art24/

Table 3. Themes from the research literature not found in study participants' comments

Themes

Related academic literature

Second-tier variables in Theory and practice Ostrom $(2007,2009)^{\dagger}$

Leadership

Resilience develops as a community builds on its strengths, and leaders can facilitate U5: Leadership and that process (Berkes and Ross 2013). Leadership is one important component of strong, entrepreneurship effective governance institutions, alongside robust rules in use and active enforcement of those rules (Seixas and Berkes 2003).

Effective change leaders develop and communicate a vision and influence how other actors perceive reality and create meaning. They mobilize support for the change vision, help manage conflict, initiate partnerships, coordinate learning, and support feedback processes and information circulation (Folke et al. 2005, Folke 2006, Olsson et al. 2006). Leaders help establish social attitudes - such as a "culture of conservation" or

"conservation ethic" as well as a broad embrace of collaboration-all of which support adaptive capacity (Engle 2013). Effective leaders may reduce typical delays between recognizing and mitigating a problem by inducing shifts in public opinion to demand action (Scheffer et al. 2003).

No single style of leadership is always best; leaders must respond dynamically to shifting realities (Walker et al. 2006). In more resilient systems with higher adaptive capacity, leaders tend to emerge within self-organizing processes to fit new roles such as boundary spanning and knowledge brokering (Pahl-Wostl 2009).

"[D]eliberate transformation involves breaking down the resilience of the old and building the resilience of the new" (Folke et al. 2010:7). Leaders can facilitate such change or they can create obstacles to change if they embrace a rigid vision focused on status quo stability (Olsson et al. 2006).

Leadership may be concentrated in one person or dispersed, and leaders may be state or nonstate actors (Clarvis and Engle 2015); having several leaders contributes to adaptability (Olsson et al. 2006).

"Transition arenas" are small networks of "frontrunners" selected for their vision, foresight, team play, and authority and influence within other networks (Loorbach 2010:173). Sometimes called "champions," they may be seen as thought leaders or opinion leaders operating within the transition space but outside normal policy-making channels (Bos and Brown 2012:1350).

Transformational leaders are often policy entrepreneurs (Huitema and Meijerink 2010, Olsson et al. 2014) and institutional entrepreneurs (Westley et al. 2011) as well.

Even strong and able social coordination will be inadequate if the societal context is plagued by official corruption (Pahl-Wostl and Knieper 2014). Thus, leaders need to combat corruption first and foremost.

Equity and social justice

Distributive justice and participatory justice, including access for current and future users, are fundamental principles for sustainable water governance (Wiek and Larson 2012).

Income inequality exacerbates vulnerability to environmental change and lowers adaptive capacity (Yohe and Tol 2002, Dow et al. 2006, Eakin and Lemos 2006). Livelihoods become vulnerable to shocks and stresses when people lack endowments, such as income, wealth, or alternative opportunities to earn, that can be exchanged for food and other vital commodities (Adger 2006).

Disproportionately powerful stakeholders, who often benefit from the status quo, may resist social-ecological system (SES) changes that threaten their vested interests. The more concentrated the society's power and resources, the greater the effects of inequity on SES transition potential (Scheffer et al. 2003). In some cases, however, it will be the marginalized poor rather than robust elites who try to protect their short-term interests in protecting the status quo (Robards et al. 2011).

Power relations within an SES influence which voices will be privileged and which will be marginalized or silenced (Fabinyi et al. 2014).

Redistribution and sharing of power enables greater collaboration (Olsson et al. 2014). Equity in resource access and allocation helps support resilience-enhancing practices among local people (Seixas and Berkes 2003).

There may be trade-offs between equitable sharing of decision-making power and capacity to make technically complicated choices when necessary (Engle and Lemos 2010).

The community's overall level of aggregate resources also matters. Increased development lowers vulnerability (Brooks et al. 2005). More affluent communities demonstrate greater adaptive capacity (Posey 2009, Knieper and Pahl-Wostl 2016).
S1: Economic development

GS4: Property-rights systems

U2: Socioeconomic attributes of users

O1: Social performance measures (includes equity) Interactions (between factors); $\mathrm{O}=$ Outcomes.

Study participants said almost nothing about the role of leaders or leadership. One interviewee mentioned a single individual in his region who had championed climate change planning.
This theme did not emerge in interviews or focus groups. 
Responses to this article can be read online at:

http://www.ecologyandsociety.org/issues/responses. $\mathrm{php} / 10537$

\begin{abstract}
Acknowledgments:
We would like to thank the participants in this study for taking time from their busy schedules to speak with us and providing feedback on earlier drafts. Many thanks to Doug Yoder and Kevin Morley for advice given at multiple stages of analysis. We are grateful to Cynthia Lane and Alex Gerling for patient facilitation in organizing focus groups at the American Water Works Association's annual conference in Chicago. Special thanks to Maegan Eichinger for detailed assistance in the data collection process and general support provided in the completion of this study. Lastly, we would like to thank American University and the University of North Carolina Wilmington for supporting data collection, and the American University Library for funding open-access publication.
\end{abstract}

\section{LITERATURE CITED}

Adger, W. N. 2003. Social capital, collective action, and adaptation to climate change. Economic Geography 79:387-404. http://dx.doi.org/10.1111/j.1944-8287.2003.tb00220.x

Adger, W. N. 2006. Vulnerability. Global Environmental Change 16:268-281. http://dx.doi.org/10.1016/j.gloenvcha.2006.02.006

Adger, N., T. P. Hughes, C. Folke, S. R. Carpenter, and J. Rockstrom. 2005. Social-ecological resilience to coastal disasters. Science 309:1036-1039. http://dx.doi.org/10.1126/science.1112122

Allenby, B., and J. Fink. 2005. Toward inherently secure and resilient societies. Science 309:1034-1036. http://dx.doi. org/10.1126/science.1111534

Araral, E., Jr. 2008. Public provision for urban water: getting prices and governance right. Governance 21:527-549. http://dx. doi.org/10.1111/j.1468-0491.2008.00412.x

Berkes, F., and H. Ross. 2013. Community resilience: toward an integrated approach. Society \& Natural Resources 26:5-20. http:// dx.doi.org/10.1080/08941920.2012.736605

Berkes, F., and C. S. Seixas. 2005. Building resilience in lagoon social-ecological systems: a local-level perspective. Ecosystems 8:967-974. http://dx.doi.org/10.1007/s10021-005-0140-4

Biggs, R., M. Schluter, D. Biggs, E. Bohensky, et al. 2012. Toward principles for enhancing the resilience of ecosystem services. Annual Review of Environment and Resources 37:421-428. http:// dx.doi.org/10.1146/annurev-environ-051211-123836

Bos, J. J., and R. R. Brown. 2012. Governance experimentation and factors of success in socio-technical transitions in the urban water sector. Technological Forecasting and Social Change 79:1340-1353. http://dx.doi.org/10.1016/j.techfore.2012.04.006

Brooks, N., W. N. Adger, and M. P. Kelly. 2005. The determinants of vulnerability and adaptive capacity at the national level and the implications for adaptation. Global Environmental Change 15:151-163. http://dx.doi.org/10.1016/j.gloenvcha.2004.12.006
Brown, R. R. 2005. Impediments to integrated urban stormwater management: the need for institutional reform. Environmental Management 36:455-468. http://dx.doi.org/10.1007/s00267-004-0217-4

Brown, R. R. 2008. Local institutional development and organizational change for advancing sustainable urban water futures. Environmental Management 41:221-233. http://dx.doi. org/10.1007/s00267-007-9046-6

Carpenter, S. R., J. J. Cole, M. L. Pace, R. Batt, and W. A. Brock. 2011. Early warnings of regime shifts: a whole-ecosystem experiment. Science 332:1079-1082. http://dx.doi.org/10.1126/ science. 1203672

Clarvis, M. H., and N. L. Engle. 2015. Adaptive capacity of water governance arrangements: a comparative study of barriers and opportunities in Swiss and US states. Regional Environmental Change 15:517-527. http://dx.doi.org/10.1007/s10113-013-0547$\mathrm{y}$

Corbin, J., and A. Strauss. 2015. Basics of qualitative research: techniques and procedures for developing grounded theory. Fourth edition. Sage, Thousand Oaks, California, USA. http://dx.doi. org/10.4135/9781452230153

de Graaf, R., and R. van der Brugge. 2010. Transforming water infrastructure by linking water management and urban renewal in Rotterdam. Technological Forecasting and Social Change 77:1282-1291. http://dx.doi.org/10.1016/j.techfore.2010.03.011

Dietz, T., E. Ostrom, and P. C. Stern. 2003. The struggle to govern the commons. Science 302(5652):1907-1912. http://dx.doi. org/10.1126/science.1091015

Djalante, R., C. Holley, and F. Thomalla. 2011. Adaptive governance and managing resilience to natural hazards. International Journal of Disaster Risk Reduction 2:1-14. http://dx. doi.org/10.1007/s13753-011-0015-6

Dow, K., R. Kasperson, and M. Bohn. 2006. Exploring the social justice implications of adaptation and vulnerability. Pages 79-96 in N. Adger, J. Paavola, S. Huq, and M. J. Mace, editors. Fairness in adaptation to climate change. MIT Press, Cambridge, Massachusetts, USA.

Eakin, H., and M. C. Lemos. 2006. Adaptation and the state: Latin America and the challenge of capacity-building under globalization. Global Environmental Change 16:7-18. http://dx. doi.org/10.1016/j.gloenvcha.2005.10.004

Engle, N. L. 2011. Adaptive capacity and its assessment. Global Environmental Change 21:647-656. http://dx.doi.org/10.1016/j. gloenvcha.2011.01.019

Engle, N. L. 2013. The role of drought preparedness in building and mobilizing adaptive capacity in states and their community water systems. Climate Change 118:291-306. http://dx.doi. org/10.1007/s10584-012-0657-4

Engle, N. L., and M. C. Lemos. 2010. Unpacking governance: building adaptive capacity to climate change of river basins in Brazil. Global Environmental Change 20:4-13. http://dx.doi. org/10.1016/j.gloenvcha.2009.07.001

Evered, R., and M. R. Louis. 1981. Alternative perspectives in the organizational sciences: "inquiry from the inside" and 
"inquiry from the outside." Academy of Management Review 6:385-395.

Fabinyi, M., L. Evans, and S. J. Foale. 2014. Social-ecological systems, social diversity, and power: insights from anthropology and political ecology. Ecology and Society 19:28. http://dx.doi. org/10.5751/ES-07029-190428

Farrelly, M., and R. Brown. 2011. Rethinking urban water management: experimentation as a way forward? Global Environmental Change 21:721-732. http://dx.doi.org/10.1016/j. gloenvcha.2011.01.007

Folke, C. 2006. Resilience: the emergence of a perspective for social-ecological systems analyses. Global Environmental Change 16:253-267. http://dx.doi.org/10.1016/j.gloenvcha.2006.04.002

Folke, C., S. R. Carpenter, B. Walker, M. Scheffer, T. Chapin, and J. Rockström. 2010. Resilience thinking: integrating resilience, adaptability and transformability. Ecology and Society 15:20. http://dx.doi.org/10.5751/ES-03610-150420

Folke, C., T. Hahn, P. Olsson, and J. Norberg. 2005. Adaptive governance of social-ecological systems. Annual Review of Environment and Resources 30:441-473. http://dx.doi.org/10.1146/ annurev.energy.30.050504.144511

Gallopin, G. C. 2006. Linkages between vulnerability, resilience, and adaptive capacity. Global Environmental Change 16:293-303. http://dx.doi.org/10.1016/j.gloenvcha.2006.02.004

Garmestani, A. S., and M. H. Benson. 2013. A framework for resilience-based governance of social-ecological systems. Ecology and Society 18:9. http://dx.doi.org/10.5751/ES-05180-180109

Gunderson, L. H., S. R. Carpenter, C. Folke, P. Olsson, and G. Peterson. 2006. Water RATs (resilience, adaptability, and transformability) in lake and wetland socio-ecological systems. Ecology and Society 11:16. http://dx.doi.org/10.5751/ES-01556-110116

Heaney, J. P., L. Wright, and D. Sample. 2000. Sustainable urban water management. Chapter 3 in R. Field, J. P. Heaney, and R. Pitt, editors. Innovative urban wet-weather flow management systems. Technomic Publishing, Lancaster, Pennsylvania, USA.

Holling, C. S., and L. H. Gunderson. 2002. Resilience and adaptive cycles. Pages 25-62 in L. H. Gunderson and C. S. Holling, editors. Panarchy: understanding transformations in human and natural systems. Island Press, Washington, D.C., USA.

Huitema, D., and S. Meijerink. 2010. Realizing water transitions: the role of policy entrepreneurs in water policy change. Ecology and Society 15:26. http://dx.doi.org/10.5751/ES-03488-150226

Huntjens, P., L. Lebel, C. Pahl-Wostl, J. Camkin, R. Schulze, and N. Kranz. 2012. Institutional design propositions for the governance of adaptation to climate change in the water sector. Global Environmental Change 22:67-81. http://dx.doi.org/10.1016/ j.gloenvcha.2011.09.015

Jørgensen, U. 2012. Mapping and navigating transitions-the multi-level perspective compared with arenas of development. Research Policy 41:996-1010. http://dx.doi.org/10.1016/j. respol.2012.03.001

Knieper, C., and C. Pahl-Wostl. 2016. A comparative analysis of water governance, water management, and environmental performance in river basins. Water Resources Management 30:2161-2177. http://dx.doi.org/10.1007/s11269-016-1276-Z

Koop S. H. A., and C. J. van Leeuwen. 2015. Assessment of the sustainability of water resources management: a critical review of the City Blueprint Approach. Water Resources Management 29:5649-5670. http://dx.doi.org/10.1007/s11269-015-1139-z

Lebel, L., J. M. Anderies, B. Campbell, C. Folke, S. HatfieldDodds, T. P. Hughes, and J. Wilson. 2006. Governance and the capacity to manage resilience in regional social-ecological systems. Ecology and Society 11:19. http://dx.doi.org/10.5751/ ES-01606-110119

Lebel, L., E. Nikitina, C. Pahl-Wostl, and C. Knieper. 2013. Institutional fit and river basin governance: a new approach using multiple composite measures. Ecology and Society 18:1. http://dx. doi.org/10.5751/ES-05097-180101

Li, Z., S. Xu, and Y. Liming. 2018. A systematic literature mining of Sponge City: trends, foci and challenges standing ahead. Sustainability 10:1182. http://dx.doi.org/10.3390/su10041182

Loorbach, D. 2010. Transition management for sustainable development: a prescriptive, complexity-based governance framework. Governance 23:161-183. http://dx.doi.org/10.1111/ j.1468-0491.2009.01471.x

Marlow, D. R., D. J. Beale, and S. Burn. 2010. A pathway to a more sustainable water sector: sustainability-based asset management. Water Science \& Technology 61:1245-1255. http:// dx.doi.org/10.2166/wst.2010.043

Marlow, D. R., M. Moglia, S. Cook, and D. J. Beale. 2013. Towards sustainable urban water management: a critical reassessment. Water Research 47:7150-7161. http://dx.doi. org/10.1016/j.watres.2013.07.046

Marschke, M. J., and F. Berkes. 2006. Exploring strategies that build livelihood resilience: a case from Cambodia. Ecology and Society 11:42. http://dx.doi.org/10.5751/ES-01730-110142

McGinnis, M. D., and E. Ostrom. 2011. Reflections on Vincent Ostrom, public administration, and polycentricity. Public Administration Review 72:15-25. http://dx.doi.org/10.1111/ j.1540-6210.2011.02488.x

Mostert, E., C. Pahl-Wostl, Y. Rees, B. Searle, D. Tàbara, and J. Tippett. 2007. Social learning in European river-basin management: barriers and fostering mechanisms from 10 river basins. Ecology and Society 12:19. http://dx.doi.org/10.5751/ ES-01960-120119

Newig, J., D. Gunther, and C. Pahl-Wostl. 2010. Synapses in the network: learning in governance networks in the context of environmental management. Ecology and Society 15:24. http:// dx.doi.org/10.5751/ES-03713-150424

O'Brien, K. 2012. Global environmental change II: from adaptation to deliberate transformation. Progress in Human Geography 36:667-676. http://dx.doi.org/10.1177/0309132511425767

Olsson, P., C. Folke, and F. Berkes. 2004. Adaptive comanagement for building resilience in social-ecological systems. Environmental Management 34:75-90. http://dx.doi.org/10.1007/s00267-003-0101-7 
Olsson, P., V. Galaz, and W. J. Boonstra. 2014. Sustainability transformations: a resilience perspective. Ecology and Society 19:1. http://dx.doi.org/10.5751/ES-06799-190401

Olsson, P., L. H. Gunderson, S. R. Carpenter, P. Ryan, L. Lebel, C. Folke, and C. S. Holling. 2006. Shooting the rapids: navigating transitions to adaptive governance of social-ecological systems. Ecology and Society 11:18. http://dx.doi.org/10.5751/ES-01595-110118

Ong, B. K. 2012. Grounded theory method (GTM) and the abductive research strategy (ARS): a critical analysis of their differences. International Journal of Social Research Methodology 15:417-432. http://dx.doi.org/10.1080/13645579.2011.607003

Ospina, S. M., M. Esteve, and S. Lee. 2018. Assessing qualitative studies in public administration research. Public Administration Review 78:593-605. http://dx.doi.org/10.1111/puar.12837

Ostrom, E. 1990. Governing the commons: the evolution of institutions for collective action. Cambridge University Press, New York, New York, USA.

Ostrom, E. 2007. A diagnostic approach for going beyond panaceas. Proceedings of the National Academy of Sciences of the United States of America 104:15181-15187. http://dx.doi. org/10.1073/pnas.0702288104

Ostrom, E. 2009. A general framework for analyzing sustainability of social-ecological systems. Science 325:419-422. http://dx.doi.org/10.1126/science.1172133

Pahl-Wostl, C. 2009. A conceptual framework for analysing adaptive capacity and multi-level learning processes in resource governance regimes. Global Environmental Change 19:354-365. http://dx.doi.org/10.1016/j.gloenvcha.2009.06.001

Pahl-Wostl, C. 2017. An evolutionary perspective on water governance: from understanding to transformation. Water Resources Management 31:2917-2932. http://dx.doi.org/10.1007/ s11269-017-1727-1

Pahl-Wostl, C., G. Holz, B. Kastens, and C. Knieper. 2010. Analyzing complex water governance regimes: the Management and Transition Framework. Environmental Science \& Policy 13:571-581. http://dx.doi.org/10.1016/j.envsci.2010.08.006

Pahl-Wostl, C., and C. Knieper. 2014. The capacity of water governance to deal with the climate change adaptation challenge: using fuzzy set Qualitative Comparative Analysis to distinguish between polycentric, fragmented and centralized regimes. Global Environmental Change 29:139-154. http://dx.doi.org/10.1016/j. gloenvcha.2014.09.003

Pahl-Wostl, C., J. Sendzimir, P. Jeffrey, J. Aerts, G. Berkamp, and K. Cross. 2007. Managing change toward adaptive water management through social learning. Ecology and Society 12:30. http://dx.doi.org/10.5751/ES-02147-120230

Parthasarathy, A., and U. Natesan. 2015. Coastal vulnerability assessment: a case study on erosion and coastal change along Tuticorin, Gulf of Mannar. Natural Hazards 75:1713-1729. http://dx.doi.org/10.1007/s11069-014-1394-y

Posey, J. 2009. The determinants of vulnerability and adaptive capacity at the municipal level: evidence from floodplain management programs in the United States. Global Environmental Change 19:482-493. http://dx.doi.org/10.1016/j.gloenvcha.2009.06.003
Raven, R., S. Van den Bosch, and R. Weterings. 2010. Transitions and strategic niche management: towards a competence kit for practitioners. International Journal of Technology Management 51:57-74. http://dx.doi.org/10.1504/IJTM.2010.033128

Ries, M., M. Trotz, and K. Vairavarmoorthy. 2016. 'Fit-forpurpose' sustainability index: a simplified approach for U.S. water utility sustainability assessment. Water Practice \& Technology 11:35-47. http://dx.doi.org/10.2166/wpt.2016.009

Robards, M. D., M. L. Schoon, C. L. Meek, and N. L. Engle. 2011. The importance of social drivers in the resilient provision of ecosystem services. Global Environmental Change 21:522-529. http://dx.doi.org/10.1016/j.gloenvcha.2010.12.004

Scheffer, M., F. Westley, and W. Brock. 2003. Slow response of societies to new problems: causes and costs. Ecosystems 6:493-502. http://dx.doi.org/10.1007/PL00021504

Schot, J., and F. W. Geels. 2008. Strategic niche management and sustainable innovation journeys: theory, findings, research agenda, and policy. Technology Analysis \& Strategic Management 20:537-554. http://dx.doi.org/10.1080/09537320802292651

Seixas, C. S., and F. Berkes. 2003. Dynamics of social-ecological changes in a lagoon fishery in southern Brazil. Pages 271-298 in F. Berkes, J. Colding, and C. Folke, editors. Navigating socialecological systems: building resilience for complexity and change. Cambridge University Press, Cambridge, UK. http://dx.doi. org/10.1017/CBO9780511541957.017

Tol, R. S. J., and G. W. Yohe. 2007. The weakest link hypothesis for adaptive capacity: an empirical test. Global Environmental Change 17:218-227. http://dx.doi.org/10.1016/j.gloenvcha.2006.08.001

Walker, B. H., J. M. Anderies, A. P. Kinzig, and P. Ryan. 2006. Exploring resilience in social-ecological systems through comparative studies and theory development: introduction to the special issue. Ecology and Society 11:12. http://dx.doi. org/10.5751/ES-01573-110112

Walker, B. H., C. S. Holling, S. R. Carpenter, and A. Kinzig. 2004. Resilience, adaptability and transformability in social-ecological systems. Ecology and Society 9:5. http://dx.doi.org/10.5751/ ES-00650-090205

Westley, F., P. Olsson, C. Folke, T. Homer-Dixon, H. Vredenburg, D. Loorbach, J. Thompson, M. Nilsson, E. Lambin, J. Sendzimir, B. Banarjee, V. Galaz, and S. van der Leeuw. 2011. Tipping toward sustainability: emerging pathways of transformation. $A M B I O$ 40:762-780. http://dx.doi.org/10.1007/s13280-011-0186-9

Wiek, A., and K. L. Larson. 2012. Water, people, and sustainability — a systems framework for analyzing and assessing water governance regimes. Water Resources Management 26:3153-3171. http://dx.doi.org/10.1007/s11269-012-0065-6

Yin, R. K. 2016. Qualitative research from start to finish. Second edition. The Guilford Press, New York, New York, USA.

Yohe, G., and R. S. J. Tol. 2002. Indicators for social and economic coping capacity-moving toward a working definition of adaptive capacity. Global Environmental Change 12:25-40. http:// dx.doi.org/10.1016/S0959-3780(01)00026-7 
Young, O. R. 2010. Institutional dynamics: resilience, vulnerability and adaptation in environmental and resource regimes. Global Environmental Change 20:378-385. http://dx.doi. org/10.1016/j.gloenvcha.2009.10.001

Young, O. R. 2011. Land use, environmental change, and sustainable development: the role of institutional diagnostics. International Journal of the Commons 5:66-85. http://dx.doi. org/10.18352/ijc. 244 


\section{Appendix 1: Interview Guide}

1. Tell me about your agency and its priorities.

a. Boundaries? Whom do you serve?

2. How does your agency fit into the broader water governance system for your city or area?

a. Main relationships/connections?

3. Tell me about long-term goals and priorities for water in your city.

a. Where do these goals come from?

b. Are these the right goals? Would you add anything or make any changes?

4. What are the main challenges/obstacles to achieving the goals?

a. Is your agency structured effectively?

b. Are broader decision-making processes organized effectively, or are there challenges with that?

c. Is politics an obstacle? If so, how?

d. Is distribution of resources and power right?

5. In your opinion, are there better and worse ways of responding to the challenges?

a. How is your city responding to the challenges and pursuing the goals/priorities?

b. What are the bright spots? Are some efforts especially promising? Could they be built up?

c. Where is improvement needed? What could be done better? Are additional activities needed? And if so, what are they?

6. Is your agency/city government learning from its experience with regard to the goals? Are the lessons being translated into action?

a. Do you look to any other cities as role models? Are other cities making more progress, and if so, how are they doing it?

7. Is it all up to city governments to fix the problems? Who else could or should be involved in finding solutions and pursuing the goals?

a. Is your city already partnering with any of these people or organizations? Which ones?

b. Tell me about what they are doing together.

c. How is it going?

8. What are the main lessons from your city that you would like to share with others facing similar challenges?

9. Academics talk a lot about resilience. Is that a term that your agency uses/your city? What does it mean to you?

10. What have I forgotten to ask you about? What else would you like to add? 